This is a post-peer-review, pre-copyedit version of an article published in Journal of International Business Studies. The final authenticated version is available online at:

https://doi.org/10.1057/s41267-019-00271-3

\title{
Capturing the role of societal affinity in cross-border mergers with the Eurovision Song Contest
}

\author{
Antonios Siganos* \\ Senior Lecturer in Finance \\ Adam Smith Business School \\ Accounting and Finance Subject \\ University of Glasgow \\ Glasgow, G12 8QQ, UK \\ a.siganos@accfin.gla.ac.uk \\ Isaac T. Tabner \\ Senior Lecturer in Finance \\ Stirling Management School \\ Accounting and Finance Division \\ University of Stirling \\ Stirling, FK9 4LA, UK \\ isaac.tabner@stir.ac.uk
}

This version: $2^{\text {nd }}$ September 2019

*Correspondence: Adam Smith Business School, Accounting and Finance Subject, University of Glasgow, Scotland, UK, Phone: +44(0) 1413304809, E-mail: a.siganos@accfin.gla.ac.uk

\section{ACKNOWLEDGEMENTS}

We are grateful to Professor Mark Peterson (Area Editor) and to three anonymous reviewers for valuable comments on earlier drafts of this paper. We are thankful to Seth Armitage, Jay Dahya, Jo Danbolt, Mark Goergen, Iftekhar Hasan, Frank Hong Liu, Richard Taffler, Ioannis Tsalavoutas and Pauline Weetman for their helpful comments, and also to Gillian MacIver for the manual data collection from the Google Trends website. 
Capturing the role of societal affinity in cross-border mergers with the Eurovision Song Contest

\begin{abstract}
This paper demonstrates the effectiveness of voting bias in the Eurovision Song Contest as a means of capturing societal affinity. More than 180 million viewers from more than 40 countries watch the Eurovision Song Contest every year and vote for their favorite songs. Societal affinity between participating countries leads to systematic bias in voting patterns as each song represents a country. Using cross-border mergers as a proxy for international business exchanges, we demonstrate how voting bias provides a simple, freely available, and dynamic means of capturing societal affinity between countries that complements other metrics of affinity and distance.
\end{abstract}

Keywords: Eurovision Song Contest; Societal Affinity; Cross-Border Mergers.

JEL classification: G1; G34; Z1 . 


\section{INTRODUCTION}

Taking inspiration from the body of literature that examines the information content of voting bias observable within the Eurovision Song Contest (e.g., Yair, 2018), we present voting bias in the Eurovision Song Contest as a measure of societal affinity. We propose that societal affinity within pairs of countries (dyads) is imperfectly correlated with distance arising from geography, economic factors, and culture. Unlike distance, societal affinity can take negative as well as neutral and positive values.

Each May, participating countries submit their song to the contest and the public votes to determine the best original song, and hence the winning country. Artists who started their career at the Eurovision Song Contest include ABBA, Celine Dion, and Julio Iglesias. Approximately 180 million viewers watch the contest and over 10 million votes are cast every year. However, the competition is often regarded as severely biased due to consistent voting patterns within dyads such as Cyprus and Greece, or Ireland and the UK. For example, the veteran Irish journalist, Terry Wogan, declared that the Eurovision Song Contest is no longer a musical contest (Peterkin, 2008). Voting for a favorite song is primarily a system-one cognitive process (Kahneman, 2011). Votes are driven by inner subconscious beliefs but modified by social interactions with associates and preconceptions about the nations represented by each song. There is no obviously right or wrong answer. The stakes are also low enough to discount the possibility that respondents are overly analytical or self-conscious when casting their vote.

We test our proposition using cross-border mergers as a proxy for international business (IB) exchanges. In line with our prediction, more mergers occur between countries having greater societal affinity. Our finding that societal affinity moderates the effects of distance complements distance measures commonly used in IB research (e.g., Beugelsdijk, Kostova \& Roth, 2017; Dinner, Kushwaha \& Steenkamp, 2019). 


\section{SOCIETAL AFFINITY}

Although societal affinity influences human decisions in ways not captured by traditional distance studies, societal affinity has received relatively little attention in IB research. To redress this, we show its relevance for IB by hypothesizing that the number of cross-border mergers within country dyads is positively associated with societal affinity. Societal affinity is related with familiarity in the sense of an uncritical link of togetherness, such as sharing language or religion. Although some studies examine the relationship between familiarity and managers' decisions (e.g., Clark, Li \& Shepherd, 2018), familiarity and affinity differ in that familiarity may also lead to contempt (Norton, Frost \& Ariely, 2007).

Several factors potentially determine the level of affinity towards a country. For example, media coverage should have a relatively homogenous influence on citizens' affinity within dyadic pairs. Natural disasters such as earthquakes, storms, fires and wars could also influence the affinity of a large percentage of citizens of one country for citizens of another country. Likewise, school curricula may influence young peoples' affinity for a country (e.g., Barton \& McCully, 2005) and these feelings are likely to persist later in life. The driver of decisions taken due to societal affinity is not necessarily subconscious or irrational. For example, countries that share similar cultures may have fewer synergies and complementarities leading some corporate managers to engage their firms with counterparts in psychically distant countries to benefit from diversity (Shenkar, 2012).

Our model of societal affinity characterized by Exhibit 1, goes beyond standard distance metrics by capturing the degree to which characteristics are liked and sympathized, both by actors who share them, and those who do not, i.e. the attraction of opposites. We posit that, in and of itself, closeness is an insufficient condition to enable the initiation and development of information exchange networks that facilitate the high value knowledge exchange described by the revised Uppsala Process model (Johanson \& Vahlne, 2009). Instead we argue that affinity is an important moderator of distance that influences human decisions. Whether in marriage, corporate mergers, or international relations, in the absence of affinity, it is hard to conceive of the trusting committed relationship development necessary for the sharing of valuable or sensitive information. 
Insert Exhibit 1 about here

The upper left quadrant of Exhibit 1 - represents situations in which psychic proximity, ease of communication, mutual understanding, recognition, appreciation and sympathy enable psychically close societies to like each other more than distant ones. One's level of sympathy can also be influenced by the closeness of minds and emotions, familiarity, the feeling of intimacy, perceiving something in another that is in common with oneself, and any bodily similarity (Sally, 2000). Countries that share the same language, religion, history, and a geographical border, or whose capitals are relatively close, are expected to share a high level of societal affinity.

The upper right quadrant of Exhibit 1, is characterized by dyadic relations such as those between Japan and the UK, two countries that, appear psychically distant, both in geography and culture (for example, uncertainty avoidance and individualism). Yet both countries share high levels of societal affinity having benefitted from exchanges, among others, in whisky distilling, manufacturing, sports, film, manga and music.

Continuing clockwise to the bottom right quadrant of Exhibit 1, Arikan \& Shenkar (2013) find that the probability of forming an alliance decreases within country dyads that share animosity and fear. Such dyads typically have a history of conflict, thus making business exchanges costly and subject to liability of foreignness. Examples include the US and Iran, or the US and China (e.g. Huawei).

The bottom left quadrant of Exhibit 1 indicates that closeness may reduce transaction costs and transport costs. Still, close entities are also liable to hostile rivalry, especially if states or regions have engaged in armed conflict in the past. Greece and Turkey, are two countries for which one may expect a close interrelation, yet societal affinity within this dyad is low. Indeed, most distance metrics predict significant cross-border activity between Greece and Turkey, whereas our societal affinity measure predicts the reverse. 


\section{METHODS}

\section{Key Independent Variable - Societal Affinity}

We estimated OLS regressions focusing on the significance of societal affinity (voting bias) for IB exchanges. Following Charron (2013), we represent societal affinity as the average voting score received between each pair of countries in the Eurovision Song Contest, after subtracting the average score received across all remaining countries for the songs associated with each pair, in order to control for the quality of a song. If the bias is zero between two countries, a population's vote is determined purely by the universal appeal of the song. Voting bias reflects the societal affinity stemming from general relations between two countries. In other words, voting populations prefer bad songs from a country with which they share affinity to good songs from a country with which they share antipathy. Our main independent variable is thus societal affinity as measured by voting bias. Our sample begins in 1999 because prior to then, songs were ranked by national judges only. Voting records for the period 1999 through 2013 were accessed from the official Eurovision website (Eurovision Song Contest, 2019). The votes available are 0, 1, 2, 3, 4, 5, 6, 7, 8, 10, and 12; therefore, the voting bias can vary between minus 12 and plus 12 . The sample includes the 41 countries shown in the Online Appendix. The results indicate some typical voting patterns; for example, on average, participants in Greece and Cyprus award marks between themselves that are 7.21 points higher than the marks given to them by citizens in other countries.

\section{Dependent Variable - Cross-Border Mergers}

Cross-border mergers offer an ideal experiment in which to study IB exchanges because of the extensive number of determinants that are already established in the literature (e.g., Erel, Liao \& Weisbach, 2012). We explore whether societal affinity matters after controlling for a large number of such determinants. Our hypothesis states that other things being equal, more cross-border mergers will occur between countries that share societal affinity relative to those that do not. Our dependent variable (Ln number of Mergers) is the natural logarithm of one plus the average number of crossborder merger deals per dyad in the full period. We obtained data from Thomson OneBanker and the 
total number of deals in our sample is 13,344 . As expected, we find that the number of merger deals is especially pronounced within target and bidder firms headquartered in the UK $(3,725)$, France $(2,934)$, and Germany $(1,341)$ (details available from the authors). There are 784 country pairs (dyads) in our sample.

\section{Other Independent Variables}

We explore whether voting bias explains merger activity after adjusting for other distance proxies. From the Hofstede website (Hofstede Insights, 2019) we collect: power distance, individualism, masculinity, uncertainty avoidance, long-term orientation, and indulgence. We also used harmony, embeddedness, hierarchy, mastery, affective autonomy, intellectual autonomy, and egalitarianism, to create the Schwartz culture distance measures (Schwartz, 2008); plus trust, authority, and individualism to estimate distance using the World Values Survey (World Values Survey, 2019). In line with Kogut and Singh (1988) and Beugelsdijk, Ambos and Nell (2018), we standardized culture distance between dyads.

We control for characteristics that indicate similarities among populations (e.g., Feito-Ruiz \& Menendez-Requejo, 2011). These include the percentage of citizens speaking each other's language within in a dyad (Shared Language), and whether countries within a dyad share a primary religion, and legal origin. If two countries share the same characteristic, the dummy variable is equal to one; they need to be interpreted the opposite way to variables measuring distance or difference. Our method of identifying primary religion is based on Stulz and Williamson (2003). We used the CIA World Factbook (CIA, 2019) to identify the percentage of citizens who speak different languages in a country and to identify firms' legal origin, i.e. civil law, common law, or both civil and common law. We used the International Historical Statistics database to access the history of a country, and use a dummy variable that equals one as a control for when countries share a history within dyads. For example, in the case of Ireland it is stated that "the 26 counties of southern Ireland became the Irish Free State, an independent dominion of the British Crown with internal self-government, in 1921. Full independence was achieved in 1949” (Palgrave Macmillan Ltd, 2013, pp.32). Therefore, the United Kingdom and Ireland share history. Our continuous variable, Conflicts, measures the number of 
conflicts with at least one fatality per country dyad between 1821 and 2010 and recoded in the Correlates of War dataset (Correlates of War, 2019).

We determined the interest shown for each song using data from the Google Trends website (Google Trends, 2019). If people wish to hear a song again, they are likely to search for it online. Therefore, our measure, Song Familiarity, is a continuous variable measuring the number of years that Google search activity peaked at the maximum (100) for a country's song between one day before and three days after each competition in at least one country within each dyad. Some song names such as "believe me" or "love song" are noisy to the extent that many people may Google such terms without necessarily searching for the song in question. In order to ensure that we capture search activity for our songs we restricted the songs' familiarity in Google searches to equal 100 around the competition.

We controlled for geographic country characteristics using kilometers of shared border. We further controlled for the distance in kilometers between capital cities, since shorter distances are associated with more cross-border mergers (e.g., Ahern, Daminelli \& Fracassi, 2015), and for whether countries are in the same region (i.e. Northern Europe, Middle East) using a dummy. The geographical data are available from the CIA World Factbook.

Variables based on economic characteristics are known to influence merger activity (e.g., Erel et al., 2012). For example, large differences of corporate taxation within dyads (e.g., Huizinga \& Voget, 2009). Hence, we downloaded taxation levels from the WorldBank (WorldBank, 2019). We also used a dummy variable, to capture pairs of countries that adopted the Euro because eliminating exchange rate risk is likely to facilitate cross-border mergers, since there is no uncertainty on exchange rate movement. Economic output is controlled for by taking the natural logarithm of the average GDP per capita per country dyad (Ln GDP). More mergers are expected within dyads exhibiting high levels of economic development (e.g., Dinc \& Erel, 2013). We also controlled for the absolute distance of GDP per capita within dyads by taking the log of the absolute difference in GDP per capita using World Bank data. Small differences in GDP indicate similar stages of economic development, and therefore more likelihood of cross-border mergers. 


\section{Some Empirical Validation of our Societal Affinity Construct}

The Pearson correlations between our variables reported in Table 1 provide some validation for the use of voting bias as a measure of societal affinity, because distance measures derived from Hofstede and Schwartz, together with capitals distance are negatively related with voting bias. Also, voting bias is positively correlated with the length of a shared border between countries. Participants that share the same history, the same religion, or the same region also exhibit a high level of voting bias. We find no relation between voting bias and song familiarity, indicating that voting bias does not reflect music preferences. This result is not surprising considering that the UK music industry is one of the most dominant globally, but UK songs commonly receive relatively few votes in the Eurovision Song Contest.

To avoid multicollinearity in our estimations in line with Lee and Makhija (2009), we orthogonalized variables with an absolute correlation higher than 0.5 . These variables are (i) shared region, capitals distance and shared border distance, (ii) GDP and GDP difference, and (iii) distance from values taken in the Hofstede and WVS data sets. We find that conclusions of the results reported are unchanged even without orthogonalizing these variables (details available from the authors).

\section{EMPIRICAL RESULTS}

\section{Determinants of Cross-Border Mergers}

Column (1) of Table 2 reports bivariate relations between cross-border mergers, voting bias and conventional distance measures, while columns (2) to (6) report the multivariate findings. We report results for the different culture distance metrics separately in columns (2), (3) and (4). Because the WVS's cultural distance measure has a substantial number of missing values, we report results without and with WVS in columns (5) and (6), respectively.

Insert Table 2 about here

In line with our hypothesis, high voting bias (high societal affinity) is associated with more cross-border mergers, while high cultural distance captured by Hofstede and Schwartz values are 
associated with fewer cross-border mergers. The WVS's measure is not significant, perhaps due to the relatively small number of observations available within our sample. The bivariate results demonstrate that coefficients for most of the controls are in line with prior research (e.g., Erel et al., 2012).

In line with our hypothesis, the relation between voting bias and mergers is remarkably consistent across different multivariate model specifications, in some of which, the other distance measures are subsumed. A one-unit increase in voting bias is associated with $16.5 \%$ increase in the number of cross-border mergers after controlling for other determinants in column (5), so the relation is economically significant.

\section{Explanatory Power of the Determinants}

The explanatory power (R-squared) of the determinants of the number of cross-border mergers are reported in column (1) of Table 3 for each of our determinants separately. Columns (2) and (3) report the incremental R-squared for the determinants in excess of the combined R-squared when all the other variables are included together in the same model.

Voting bias explains $4.4 \%$ of the variation in the number of cross-border mergers in a bivariate analysis, and $2.5 \%$ and $2.8 \%$ using a multivariate model estimated with and without the WVS, respectively. The explanatory power of voting bias is significant to at least the $5 \%$ level. It is sixth in terms of explanatory power out of the 17 determinants among the bivariate results, and it is second and fourth among the multivariate results in columns (2) and (3), respectively. Song familiarity, Ln GDP difference, and \% shared language are some of the most consistent factors for explaining cross-border merger variation.

\section{Voting Bias for Each Side of a Country Pair Separately}

Distance metrics are normally only available as an average across each country pair and (Shenkar, 2012), so cultural distance measures exhibit an illusion of symmetry in distance between countries. We therefore performed a bidirectional test for each dyad to demonstrate the added value of voting bias. For example, we find that bias is 9.83 from Cyprus to Greece and 10.84 from Greece to Cyprus (available from the authors). 
Insert Table 4 about here

Columns (1) and (2) of Table 4 show the results with and without the use of voting bias in order to explore the additional explanatory power of voting bias. We find that voting bias explains $0.3 \%$ of the additional variation in the number of cross-border mergers. This level is lower than the one reported earlier in Table 3, but is still significant at the 5\% level. It is harder to explain the variation in the number of cross-border mergers per direction of each country pair, and as a result, the total adjusted R-squared values decrease to $28 \%$ from around $40 \%$ reported in Table 2.

As a placebo test, Column (4) reports results estimated by reversing the direction of voting bias so that the voting bias is from country $i$ to country $x$ when the cross-border mergers is actually from country $x$ to country $i$. The relation between voting bias and the number of cross-border mergers in the placebo test is insignificant as expected.

\section{DISCUSSION}

Our study has significant implications for future academic research, for businesses and for policymakers evaluating cross-border mergers. The measure developed in this study complements existing distance metrics by highlighting the significance of societal affinity and identifying a freely available measure using Eurovision Song Contest voting bias that is updated annually. Our measure can be estimated separately for each side of each country pair to explore asymmetries in societal affinity. We can test societal affinity over its full range, offering a broad picture of its importance relative to prior affinity research.

An alternative and highly cited index of societal affinity is constructed by Gartzke (1998) using country pairwise correlations of roll call voting at the United Nations General Assembly (UNGA). However, it is a measure of affinity between political leaders. In contrast, our study derives societal affinity from systematic biases in the reactions of millions of citizens of countries participating in the Eurovision Song Contest. Our measure is thus a more visceral and a more representative measure of societal affinity within dyads than the Gartzke measure. Other affinity metrics include surveys from a small number of countries (e.g., Tims \& Miller, 1986; Roth \& Romeo, 
1992; Nes, Yelkur \& Silkoset, 2014). Standardized measurement of societal affinity becomes challenging, given that terms such as familiarity, similarity and affinity are typically used interchangeably. In fact, other methods typically used to capture distance metrics are susceptible to sampling, and respondent biases and may themselves be influenced by the culture of the respondent (Harzing, 2006). Additionally, many sampling questions require respondents to think about their beliefs and values prior to survey completion.

Although voting bias data are not currently available in some regions such as the Americas, the only eligibility criteria for participating in the Eurovision Song Contest is that a country is a member of the European Broadcasting Union and that it broadcasts the competition in the current year and the previous year. Indeed, a number of the countries included in our sample are non-European: Australia competed in the contest from 2015 onwards. Furthermore, the contest was broadcast in the US in 2016 hinting that it too may take part in future competitions. Since the first contest in 1956, the number of participating countries has increased from seven to 43 in 2018. Therefore the scope of this dataset is expanding all the time.

No data are available on the demographics of citizens voting in the competition. However, it is likely that a significant percentage of voters are relatively young citizens. Young people are the ideal age-group to identify a country's culture because it is in the early formative stages of our lives that cultural identifications and perceptions are formed that tend to persist in later life (Chatman \& Flynn 2001).

For a robustness test, we used instrumental variables, such as the language used to sing a song, the position taken by each country in previous competitions, and the sequence in which a country's song appears in the competition, to investigate the possibility of reverse causality. We find that voting bias remains significant when we use these instrumental variables (details available from the online appendix). Nonetheless, it is not possible to fully eliminate the possibility of reverse causality in which merger activity influences a population's perception of another country, and hence influences voting patterns in the Eurovision Song Contest. Therefore, future studies using our measure 
of societal affinity, may benefit from applying a two-stage least square analysis to examine this issue, in line with Salomon and Shaver (2005).

\section{CONCLUSION}

We argue that societal affinity between countries facilitates IB exchanges. We then demonstrate the effectiveness of voting bias in the Eurovision Song Contest as a means of capturing societal affinity. Unlike distance, societal affinity can be either negative - reflecting animosity, or positive - reflecting affinity. Furthermore, societal affinity is imperfectly correlated with other distance metrics with the result that some dyads of distant countries share high affinity, while some dyads of 'close' countries share animosity.

When we use cross-border mergers as a proxy for IB exchanges, we find a positive relation between societal affinity and mergers. In line with our hypothesis, more (less) cross-border mergers take place when the relative voting bias is high (low). Our evidence thus demonstrates that voting bias (societal affinity) captures information that is not contained within standard measures of distance. An increasing number of countries are participating in the Eurovision Song Contest and it provides a large amount of freely available data, hence we present voting bias as a valuable instrument for future research in IB. 


\section{REFERENCES}

Ahern, K., Daminelli, D., \& Fracassi, C. 2015. Lost in translation? The effect of cultural values on mergers around the world. Journal of Financial Economics, 117(1): 165-189.

Arikan, I., \& Shenkar, O., 2013. National animosity and cross-border alliances, Academy of Management Journal, 56(6): 1516-1544.

Barton, K., \& McCully, A., 2005. History, identity, and the school curriculum in Northern Ireland: An empirical study of secondary. Journal of Curriculum Studies, 37(1): 85-116.

Beugelsdijk, S., Kostova, T., \& Roth, K. 2017. An overview of Hofstede-inspired countrylevel culture research in international business since 2006. Journal of International Business Studies, 48(1): 30-47.

Beugelsdijk, S., Ambos, B., \& Nell, P. 2018. Conceptualizing and measuring distance in international business research: Recurring questions and best practice guidelines. Journal of International Business Studies, 49(9): 1113-1137.

Charron, N. 2013. Impartiality, friendship-networks and voting behaviour: Evidence from voting patterns in the Eurovision Song Contest. Social Networks, 35(3): 484-497.

Chatman, J., \& Flynn, F. 2001. The influence of demographic heterogeneity on the emergence and consequences of cooperative norms in work teams. Academy of Management Journal, 44(5): 956974.

CIA. 2019. https://www.cia.gov/library/publications/the-world-factbook/. Accessed 28 August 2019.

Clark, D., Li, D., \& Shepherd, D. 2018. Country familiarity in the initial stage of foreign market selection. Journal of International Business Studies, 49(4): 442-472.

Correlates of War. 2019. http://www.correlatesofwar.org/data-sets. Accessed 28 August 2019.

Dinc, I., \& Erel, I. 2013. Economics nationalism in mergers and acquisitions. Journal of Finance, 68(6): 2471-2514.

Dinner, I., Kushwaha, T., \& Steenkamp, J-B. 2019. Psychic distance and performance of MNCs during marketing crises. Journal of International Business Studies, 50(3):339-364. 
Erel, I., Liao, R., \& Weisbach, M. 2012. Determinants of cross-border mergers and acquisitions. Journal of Finance, 67(3): 1045-1082.

Eurovision Song Contest. 2019. https://eurovision.tv/events. Accessed 28 August 2019.

Feito-Ruiz, I., \& Menendez-Requejo, S. 2011. Cross-border mergers and acquisitions in different legal environments. International Review Law and Economics, 31(3): 169-187.

Gartzke, E. 1998. Kant we all just get along? Opportunity, willingness and the origins of the Democratic Peace. American Journal of Political Science, 42(1): 1 - 27.

Google Trends. 2019. https://trends.google.com/trends/?geo=US. Accessed 28 August 2019.

Harzing, A. 2006. Response styles in cross-national survey research: A 26-country study. International Journal of Cross-Cultural Management, 6(2): 243-266.

Hofstede insights. 2019. https://www.hofstede-insights.com/product/compare-countries/. Accessed 28 August 2019.

Huizinga, H., \& Voget, J. 2009. International taxation and the direction and volume of crossborder M\&As. Journal of Finance, 64(3): 1217-1249.

Johanson, J., \& Vahlne, J.E. 2009. The Uppsala internationalization process model revisited: From liability of foreignness to liability of outsidership, Journal of International Business Studies, 40(9): 1411-1431.

Kahneman, D. 2011. Thinking Fast and Slow, Farrar, Straus and Giroux, New York. Kogut, B., \& Singh, H. 1988. The effect of national culture on the choice of entry mode. Journal of International Business Studies, 19(3): 411-432.

Lee, S., \& Makhija, M. 2009. The effect of domestic uncertainty on the real options value of international investments. Journal of International Business Studies, 40(3):405-420.

Nes, E., Yelkur, R., \& Silkoset, R. 2014. Consumer affinity for foreign countries: Construct development, buying behavior consequences and animosity contrast. International Business Review 23(4): 774-784.

Norton, M., Frost, I., Jeana, H., \& Ariely, D. 2007. Less is more: The lure of ambiguity, or why familiarity breeds contempt. Journal of Personality and Social Psychology, 92(1): 97-105. 
Palgrave Macmillan Ltd. 2013. Introduction to the Europe Volume. In: Palgrave Macmillan Ltd (eds) International Historical Statistics. Palgrave Macmillan, London.

Peterkin, T. 2008. Eurovision Song Contest: Sir Terry Wogan may resign over bloc voting row, Telegraph, $26^{\text {th }}$ May 2008.

Roth, M., \& Romeo, J. 1992. Matching product category and country image perceptions: A framework for managing country-of-origin effects. Journal of International Business Studies, 23(3): 477-497.

Sally, D. 2000. A general theory of sympathy, mind-reading, and social interaction, with an application to the prisoners' dilemma. Theory and Methods, 39(4): 567-634.

Salomon, R., \& Shaver, M. 2005. Export and domestic sales: Their interrelationship and determinants. Strategic Management Journal, 26(9): 855-871.

Schwartz, S. 2008. The 7 Schwartz cultural value orientation scores for 80 countries. https://www.researchgate.net/publication/304715744_The_7_Schwartz_cultural_value_orientation_sc ores_for_80_countries. Accessed 28 August 2019.

Shenkar, O. 2012. Cultural distance revisited: Towards a more rigorous conceptualization and measurement of cultural differences. Journal of International Business Studies, 43(1): 1-11.

Stulz, R., \& Williamson, R. 2003. Culture, openness, and finance. Journal of Financial Economics, 70(3): 313-349.

Tims, A., \& Miller, M. 1986. Determinants of attitudes toward foreign countries. International Journal of Intercultural Relations, 10(4): 471-484.

WorldBank. 2019. https://data.worldbank.org/indicator/IC.TAX.PRFT.CP.ZS. Accessed 28 August 2019.

World Values Survey. 2019. http://www.worldvaluessurvey.org/wvs.jsp. Accessed 28 August 2019.

Yair, G. 2018. Douze point: Eurovisions and Euro-divisions in the Eurovision Song Contest Review of two decades of research. European Journal of Cultural Studies. https://journals.sagepub.com/doi/pdf/10.1177/1367549418776562. 
Exhibit 1 Theoretical schema - Societal affinity versus similarity and distance

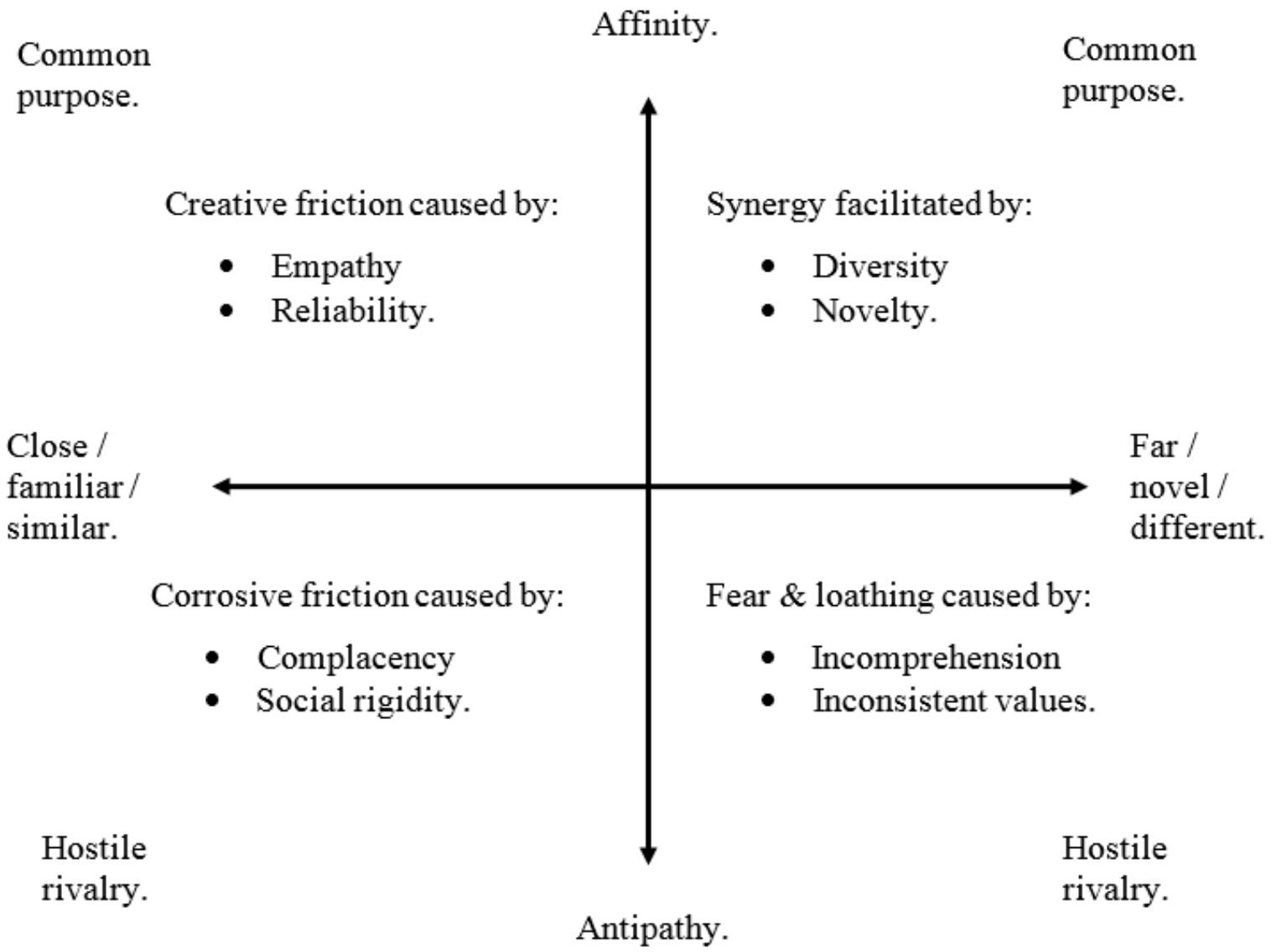


Table 1 Descriptive statistics and Pearson correlation matrix

\begin{tabular}{|c|c|c|c|c|c|c|c|c|c|c|c|c|c|}
\hline \multirow{2}{*}{1} & \multirow{2}{*}{\multicolumn{3}{|c|}{ Ln Number of Mergers }} & & \multirow{2}{*}{$\frac{\text { Mean }}{1.23}$} & \multirow{2}{*}{$\frac{\text { S.D }}{1.50}$} & \multirow[t]{2}{*}{1} & \multirow[t]{2}{*}{2} & 3 & \multicolumn{2}{|r|}{4} & \multicolumn{2}{|c|}{5} \\
\hline & & & & & & & & & & & & & \\
\hline 2 & Voting & Bias & & & -1.02 & 2.12 & 0.21 & & & & & & \\
\hline 3 & Cultura & Distanc & - Hofst & ede & 2.04 & 1.22 & -0.14 & -0.24 & & & & & \\
\hline 4 & Cultura & Distanc & - Schw & artz & 2.28 & 1.37 & -0.15 & -0.21 & 0.11 & & & & \\
\hline 5 & Cultura & Distanc & - WVS & & 2.38 & 2.54 & 0.11 & -0.19 & 0.61 & & 0.09 & & \\
\hline 6 & Ln Sha & d Bord & r Distan & & 0.52 & 1.69 & 0.19 & 0.35 & -0.22 & & 0.20 & & 15 \\
\hline 7 & Ln Cap & als Dis & nce & & 7.29 & 0.65 & -0.20 & -0.39 & 0.24 & & 0.29 & & 17 \\
\hline 8 & Song $F$ & miliarit & & & 2.07 & 1.98 & 0.41 & 0.01 & 0.02 & & 0.04 & & 16 \\
\hline 9 & Shared & anguag & & & 1.10 & 7.81 & 0.17 & 0.30 & -0.12 & & 0.11 & & 10 \\
\hline 10 & Shared & Religion & & & 0.16 & 0.37 & 0.23 & 0.18 & -0.22 & & 0.31 & & 20 \\
\hline 11 & Shared & egal O & gin & & 0.77 & 0.42 & 0.00 & -0.04 & -0.14 & & 0.03 & & 08 \\
\hline 12 & Shared & History & & & 0.06 & 0.24 & 0.23 & 0.19 & -0.15 & & 0.12 & & 11 \\
\hline 13 & Shared & Region & & & 0.09 & 0.29 & 0.08 & 0.31 & -0.31 & & 0.20 & & 20 \\
\hline 14 & Conflic & & & & 0.04 & 0.29 & 0.10 & 0.12 & -0.10 & & 0.01 & & .06 \\
\hline 15 & Tax Di & erence & & & 7.26 & 5.44 & -0.04 & 0.00 & 0.01 & & 0.11 & & 10 \\
\hline 16 & Shared & Currenc & & & 0.20 & 0.40 & 0.25 & 0.12 & -0.16 & & 0.06 & & 05 \\
\hline 17 & Ln GD & & & & 13.34 & 1.66 & 0.24 & -0.06 & 0.16 & & 0.02 & & 28 \\
\hline 18 & Ln GD & Differe & & & 13.44 & 1.99 & 0.14 & -0.06 & 0.12 & & .07 & & 24 \\
\hline & 6 & 7 & 8 & 9 & 10 & 11 & 12 & 13 & 14 & 15 & & & 17 \\
\hline 7 & -0.52 & & & & & & & & & & & & \\
\hline 8 & 0.11 & -0.01 & & & & & & & & & & & \\
\hline 9 & 0.39 & -0.22 & 0.05 & & & & & & & & & & \\
\hline 10 & 0.27 & $-\mathbf{- 0 . 3 0}$ & 0.06 & 0.13 & & & & & & & & & \\
\hline 11 & 0.17 & -0.21 & 0.04 & 0.04 & 0.02 & & & & & & & & \\
\hline 12 & 0.44 & -0.23 & 0.16 & 0.33 & 0.11 & 0.07 & & & & & & & \\
\hline 13 & 0.39 & -0.50 & 0.03 & 0.19 & 0.14 & 0.08 & 0.23 & & & & & & \\
\hline 14 & 0.21 & -0.15 & 0.11 & 0.00 & -0.02 & 0.03 & 0.17 & 0.09 & & & & & \\
\hline 15 & -0.05 & -0.02 & -0.03 & -0.01 & -0.10 & -0.19 & -0.01 & -0.02 & -0.01 & & & & \\
\hline 16 & 0.08 & -0.04 & 0.10 & 0.13 & 0.14 & -0.08 & 0.04 & 0.02 & 0.04 & 0.00 & & & \\
\hline 17 & 0.10 & -0.01 & 0.23 & 0.05 & -0.04 & 0.15 & 0.16 & -0.07 & 0.02 & -0.01 & & & \\
\hline 18 & 0.10 & 0.00 & 0.19 & 0.06 & -0.05 & 0.11 & 0.13 & -0.06 & 0.00 & 0.01 & & 05 & 0.88 \\
\hline
\end{tabular}

Notes: S.D is the standard deviation, with data combined across the years for each dyad apart from culture distance measures derived from Hofstede, Schwartz and WVS values with 470, 434 and 218 dyads respectively. Bold indicates Pearson correlation coefficients that are significant at $\mathrm{p}<0.01$. 
Table 2 Determinants of cross-border mergers

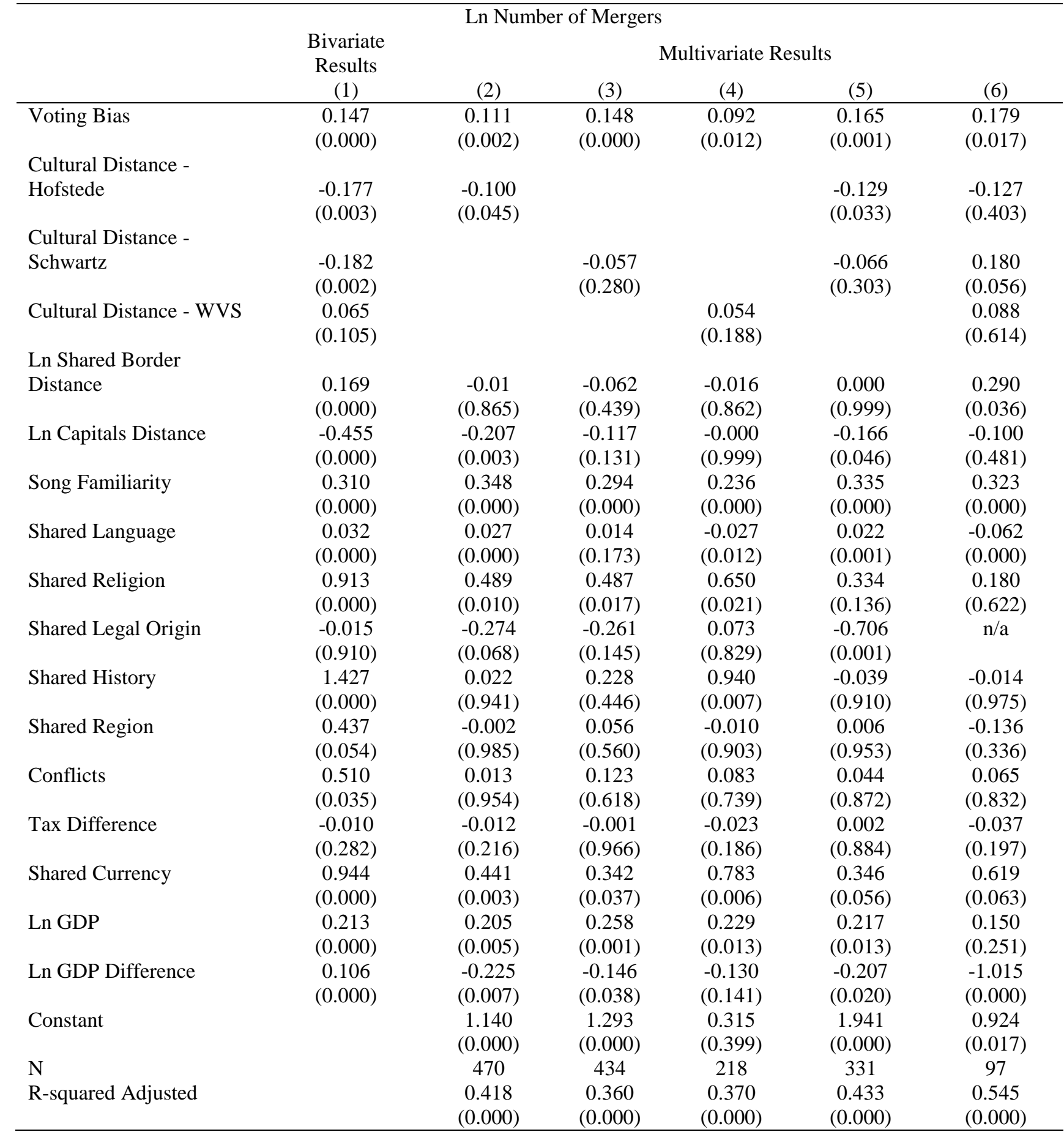

Notes: This table reports coefficients and significance levels (p-values) in parenthesis on the determinants of cross-border mergers. Our dependent variable (Ln Number of Mergers) is the natural logarithm of one plus the number of cross-border mergers within each dyad of countries. Our main independent variable is the voting bias. Shared Legal Origin's coefficient could not be estimated column 6 ("n/a") due to there being no variation on data for the particular dyad. N indicates the number of country dyads in our sample with data combined across the years within each dyad. 
Table 3 The explanatory power of the determinants for cross-border mergers

\begin{tabular}{|c|c|c|c|}
\hline & $\begin{array}{c}\text { Bivariate R-squared } \\
\text { (1) }\end{array}$ & $\begin{array}{c}\text { Number of Mergers } \\
\text { Without WVS } \\
\text { R-squared Change } \\
\text { (2) }\end{array}$ & $\begin{array}{c}\text { With WVS } \\
\text { R-squared Change } \\
\text { (3) }\end{array}$ \\
\hline Voting Bias & $\begin{array}{c}0.044 \\
(0.000)\end{array}$ & $\begin{array}{c}0.025 \\
(0.001)\end{array}$ & $\begin{array}{c}0.028 \\
(0.017)\end{array}$ \\
\hline Cultural Distance - Hofstede & $\begin{array}{c}0.019 \\
(0.003)\end{array}$ & $\begin{array}{c}0.007 \\
(0.033)\end{array}$ & $\begin{array}{c}0.007 \\
(0.378)\end{array}$ \\
\hline Cultural Distance - Schwartz & $\begin{array}{c}0.023 \\
(0.002)\end{array}$ & $\begin{array}{c}0.002 \\
(0.303)\end{array}$ & $\begin{array}{c}0.018 \\
(0.056)\end{array}$ \\
\hline Cultural Distance - WVS & $\begin{array}{c}0.012 \\
(0.105)\end{array}$ & & $\begin{array}{c}0.002 \\
(0.614)\end{array}$ \\
\hline Ln Shared Border Distance & $\begin{array}{c}0.037 \\
(0.000)\end{array}$ & $\begin{array}{c}0.000 \\
(0.999)\end{array}$ & $\begin{array}{c}0.031 \\
(0.036)\end{array}$ \\
\hline Ln Capitals Distance & $\begin{array}{c}0.038 \\
(0.000)\end{array}$ & $\begin{array}{c}0.007 \\
(0.046)\end{array}$ & $\begin{array}{c}0.003 \\
(0.481)\end{array}$ \\
\hline Song Familiarity & $\begin{array}{c}0.168 \\
(0.000)\end{array}$ & $\begin{array}{c}0.168 \\
(0.000)\end{array}$ & $\begin{array}{c}0.157 \\
(0.000)\end{array}$ \\
\hline Shared Language & $\begin{array}{c}0.028 \\
(0.000)\end{array}$ & $\begin{array}{c}0.011 \\
(0.001)\end{array}$ & $\begin{array}{c}0.011 \\
(0.001)\end{array}$ \\
\hline Shared Religion & $\begin{array}{c}0.051 \\
(0.000)\end{array}$ & $\begin{array}{c}0.005 \\
(0.136)\end{array}$ & $\begin{array}{c}0.001 \\
(0.622)\end{array}$ \\
\hline Shared Legal Origin & $\begin{array}{c}0.000 \\
(0.910)\end{array}$ & $\begin{array}{c}0.020 \\
(0.001)\end{array}$ & $\mathrm{n} / \mathrm{a}$ \\
\hline Shared History & $\begin{array}{c}0.053 \\
(0.000)\end{array}$ & $\begin{array}{c}0.000 \\
(0.910)\end{array}$ & $\begin{array}{c}0.000 \\
(0.975)\end{array}$ \\
\hline Shared Region & $\begin{array}{c}0.007 \\
(0.054)\end{array}$ & $\begin{array}{c}0.000 \\
(0.953)\end{array}$ & $\begin{array}{c}0.003 \\
(0.336)\end{array}$ \\
\hline Conflicts & $\begin{array}{c}0.009 \\
(0.035)\end{array}$ & $\begin{array}{c}0.000 \\
(0.872)\end{array}$ & $\begin{array}{c}0.000 \\
(0.832)\end{array}$ \\
\hline Tax Difference & $\begin{array}{c}0.001 \\
(0.282)\end{array}$ & $\begin{array}{c}0.000 \\
(0.884)\end{array}$ & $\begin{array}{c}0.008 \\
(0.197)\end{array}$ \\
\hline Shared Currency & $\begin{array}{c}0.065 \\
(0.000)\end{array}$ & $\begin{array}{c}0.008 \\
(0.056)\end{array}$ & $\begin{array}{c}0.022 \\
(0.063)\end{array}$ \\
\hline Ln GDP & $\begin{array}{c}0.056 \\
(0.000)\end{array}$ & $\begin{array}{c}0.014 \\
(0.013)\end{array}$ & $\begin{array}{c}0.007 \\
(0.250)\end{array}$ \\
\hline Ln GDP Difference & $\begin{array}{c}0.020 \\
(0.000)\end{array}$ & $\begin{array}{c}0.018 \\
(0.020)\end{array}$ & $\begin{array}{c}0.120 \\
(0.000)\end{array}$ \\
\hline
\end{tabular}

Notes: This table reports the explanatory power and significance levels (p-values) in parenthesis for the determinants of cross-border mergers. Column 1 shows the explanatory power of bivariate regressions, while columns 2 and 3 report the additional explanatory power of each variable beyond the explanatory power of all other variables together. Our dependent variable (Ln Number of Mergers) is the natural logarithm of one plus the number of cross-border mergers within country dyads. The shared Legal Origin coefficient could not be estimated in column 3 (" $\mathrm{n} / \mathrm{a}$ ") as there is no variation in the data for the particular country dyads. 
Table 4 The asymmetry effect of voting bias on the number of cross-border mergers

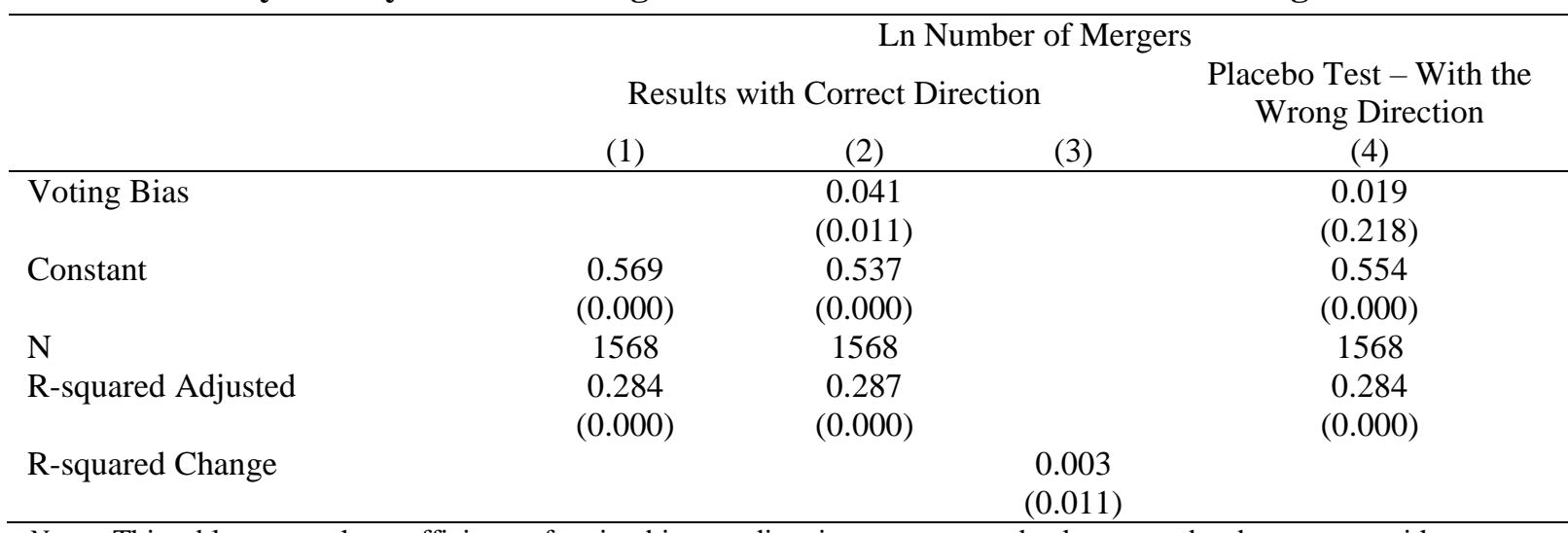

Notes: This table reports the coefficients of voting bias per direction per country dyad on cross-border mergers with significance levels (p-values) in parenthesis. In (1) we report $\mathrm{R}$ - squared adjusted and associated significance levels for the controls only without the variable of interest (voting bias), in (2) we report total $\mathrm{R}$ - squared adjusted and significance levels, while in (3) we report the total $\mathrm{R}$ - square change and significance levels when voting bias is added. We include the same control variables as in previous estimations (coefficients are available from the authors). We exclude culture dimensions from these estimations. 


\section{ABOUT THE AUTHORS}

Antonios Siganos is a Senior Lecturer in Finance at the Adam Smith Business School, University of Glasgow, UK. His current research focuses on behavioral factors that may influence the decision making of agents. He has explored amongst other variables the significance of culture, sleep deprivation, and sentiment on manager and investor decisions.

Isaac Tabner is a Senior Lecturer in Finance at the Stirling Management School, University of Stirling, UK. His current research focuses on helping households and organizations to make better financial decisions. For example, by examining: housing tenure choice; stock market participation, social engagement, and saving behavior; and the way stock prices react to changes in agency risk. 


\section{Online appendix}

Voting bias

\begin{tabular}{|c|c|c|c|c|c|c|c|c|}
\hline & Albania & Armenia & Austria & Azerbaijan & Belarus & Belgium & Bosnia & Bulgaria \\
\hline Armenia & -3.80 & & & & & & & \\
\hline Austria & 0.11 & $\mathrm{n} / \mathrm{a}$ & & & & & & \\
\hline Azerbaijan & -3.69 & -6.02 & -1.77 & & & & & \\
\hline Belarus & -1.67 & 0.94 & $\mathrm{n} / \mathrm{a}$ & 1.46 & & & & \\
\hline Belgium & -2.32 & -2.26 & -0.24 & -3.45 & -2.87 & & & \\
\hline Bosnia & 0.29 & -4.28 & 3.27 & -2.27 & -2.40 & -1.71 & & \\
\hline Bulgaria & $\mathrm{n} / \mathrm{a}$ & -0.15 & $\mathrm{n} / \mathrm{a}$ & $\mathrm{n} / \mathrm{a}$ & -6.04 & $\mathrm{n} / \mathrm{a}$ & -2.59 & \\
\hline Croatia & 0.24 & -3.63 & 1.08 & -0.55 & $\mathrm{n} / \mathrm{a}$ & -1.44 & 6.93 & $\mathrm{n} / \mathrm{a}$ \\
\hline Cyprus & -1.34 & 0.15 & -0.96 & 1.26 & -0.94 & -1.23 & -2.55 & $\mathrm{n} / \mathrm{a}$ \\
\hline Denmark & -2.58 & -4.00 & -0.75 & -4.53 & -4.77 & -0.30 & -2.23 & $\mathrm{n} / \mathrm{a}$ \\
\hline Estonia & -4.24 & -2.90 & -0.38 & -3.27 & -1.34 & -0.53 & -3.05 & $\mathrm{n} / \mathrm{a}$ \\
\hline Finland & -1.67 & -4.22 & -0.88 & -3.83 & -2.50 & -0.60 & -1.47 & -1.96 \\
\hline France & -2.19 & 2.78 & -1.65 & -3.65 & -2.30 & 0.48 & -0.59 & -1.22 \\
\hline Georgia & -3.50 & 5.90 & -2.06 & 2.99 & 3.12 & -3.07 & -3.66 & -5.52 \\
\hline Germany & -0.86 & -2.43 & 2.77 & -5.03 & -3.68 & -0.11 & -1.12 & -2.39 \\
\hline Greece & 5.95 & 1.21 & -2.12 & -1.58 & -1.88 & -0.36 & -2.50 & 6.09 \\
\hline Hungary & -1.20 & -3.36 & -0.35 & -1.51 & -3.24 & -1.02 & -3.39 & -0.98 \\
\hline Iceland & -1.56 & -2.94 & -0.26 & -3.72 & -1.04 & 0.32 & -2.84 & $\mathrm{n} / \mathrm{a}$ \\
\hline Ireland & -2.36 & -2.69 & -1.33 & -3.92 & -1.74 & 1.22 & -2.54 & -3.52 \\
\hline Israel & -1.84 & 1.21 & -1.92 & -0.22 & 2.31 & -0.89 & -1.72 & $\mathrm{n} / \mathrm{a}$ \\
\hline Italy & 4.94 & -2.82 & -2.15 & -6.75 & -3.48 & -0.82 & -2.23 & $\mathrm{n} / \mathrm{a}$ \\
\hline Latvia & -3.68 & -4.50 & 1.29 & -2.40 & -0.15 & 0.17 & -3.48 & -3.54 \\
\hline Lithuania & -2.90 & -3.11 & -1.75 & 0.82 & 1.38 & 0.44 & -2.76 & -4.02 \\
\hline Macedonia & 7.11 & -2.48 & -1.23 & -3.38 & -1.09 & -0.17 & 3.06 & 4.39 \\
\hline Malta & -1.18 & -1.66 & -0.42 & 1.82 & 1.32 & -2.57 & -1.96 & $\mathrm{n} / \mathrm{a}$ \\
\hline Moldova & -3.30 & -1.36 & -0.75 & 1.54 & 2.79 & -2.41 & -3.28 & -2.13 \\
\hline Netherlands & -2.02 & -3.10 & -0.19 & -5.92 & -3.24 & 6.31 & -0.63 & $\mathrm{n} / \mathrm{a}$ \\
\hline Norway & -2.74 & -3.77 & -0.16 & -3.53 & -2.16 & -1.07 & -0.84 & $\mathrm{n} / \mathrm{a}$ \\
\hline Poland & -2.16 & 1.81 & 0.10 & 0.60 & $\mathrm{n} / \mathrm{a}$ & 0.93 & -1.00 & $\mathrm{n} / \mathrm{a}$ \\
\hline Portugal & -2.32 & -2.78 & 1.89 & -4.53 & -1.27 & -0.95 & -2.11 & $\mathrm{n} / \mathrm{a}$ \\
\hline Romania & -2.24 & -2.61 & -1.35 & -0.62 & -3.32 & -1.13 & -2.88 & -1.59 \\
\hline Russia & -3.74 & 3.84 & -1.49 & 0.80 & 3.21 & -0.84 & -3.26 & -3.22 \\
\hline Serbia & -1.26 & -4.13 & 0.44 & -5.41 & -3.08 & -3.09 & 4.70 & -2.98 \\
\hline Slovenia & $\mathrm{n} / \mathrm{a}$ & -4.43 & 0.39 & -6.60 & -2.50 & -1.42 & 3.89 & -1.20 \\
\hline Spain & -2.19 & 0.64 & -0.79 & -3.54 & -2.33 & -0.01 & -2.57 & 0.87 \\
\hline Sweden & -2.10 & -2.93 & -1.17 & -4.52 & -3.23 & -1.20 & -0.22 & -4.52 \\
\hline Switzerland & 1.28 & -3.46 & 2.95 & -4.48 & $\mathrm{n} / \mathrm{a}$ & 2.17 & 1.67 & $\mathrm{n} / \mathrm{a}$ \\
\hline Turkey & 2.65 & -1.08 & 1.90 & 6.14 & -4.52 & 1.36 & 3.65 & -0.17 \\
\hline Ukraine & -3.28 & 0.64 & -3.82 & 3.85 & 4.35 & -2.14 & -3.45 & -5.39 \\
\hline UK & -1.57 & -2.92 & 0.45 & -3.83 & -1.86 & -1.50 & -2.24 & -1.22 \\
\hline
\end{tabular}


Continued voting bias

\begin{tabular}{|c|c|c|c|c|c|c|c|c|c|}
\hline & Croatia & Cyprus & Denmark & Estonia & Finland & France & Georgia & Germany & Greece \\
\hline Cyprus & -1.77 & & & & & & & & \\
\hline Denmark & -2.30 & -1.38 & & & & & & & \\
\hline Estonia & -1.88 & -1.65 & 0.16 & & & & & & \\
\hline Finland & -0.71 & -0.42 & -0.82 & 3.04 & & & & & \\
\hline France & -1.21 & -1.38 & -0.91 & -0.46 & -0.76 & & & & \\
\hline Georgia & -2.13 & -0.79 & -4.25 & -1.51 & -1.70 & -2.80 & & & \\
\hline Germany & -0.88 & -2.35 & 0.52 & -0.83 & -0.94 & -0.50 & -3.81 & & \\
\hline Greece & -1.04 & 7.21 & -3.56 & -1.96 & -2.59 & -1.38 & -1.13 & 0.08 & \\
\hline Hungary & 2.17 & -0.57 & -2.12 & -1.59 & 2.83 & -1.70 & -1.57 & 0.22 & -1.24 \\
\hline Iceland & -2.02 & 0.78 & 4.78 & 1.26 & 3.31 & -1.02 & -2.80 & -0.80 & -2.54 \\
\hline Ireland & -0.31 & 0.23 & 2.19 & 1.05 & -0.29 & -0.82 & -2.08 & -0.31 & -2.96 \\
\hline Israel & -1.61 & -0.90 & -0.88 & -0.32 & -1.07 & 1.97 & -0.67 & -1.21 & -1.84 \\
\hline Italy & $\mathrm{n} / \mathrm{a}$ & 0.32 & -2.82 & -1.80 & -3.17 & -0.16 & -2.53 & -1.13 & -0.24 \\
\hline Latvia & -1.37 & -3.12 & 0.31 & 2.64 & -1.70 & -1.88 & 0.80 & -0.72 & -3.30 \\
\hline Lithuania & -0.54 & -0.50 & -1.97 & 0.68 & 0.39 & -0.31 & 5.26 & -2.03 & -2.69 \\
\hline Macedonia & 4.31 & -1.61 & -2.29 & -1.44 & -2.32 & -1.34 & -3.17 & -1.56 & -2.09 \\
\hline Malta & -0.33 & 0.81 & -0.11 & -1.18 & -1.78 & -2.00 & -1.84 & -1.12 & -0.61 \\
\hline Moldova & -2.22 & -2.41 & -2.59 & -1.27 & -2.59 & -1.75 & 0.00 & -2.76 & -2.04 \\
\hline Netherlands & -1.85 & -0.26 & 0.97 & 0.16 & 1.48 & -0.86 & -3.28 & -0.40 & -2.34 \\
\hline Norway & -2.55 & -1.13 & 2.68 & -0.41 & 0.35 & -1.57 & -1.86 & -1.16 & -3.26 \\
\hline Poland & -1.18 & -1.23 & -1.04 & 1.09 & 0.02 & 0.16 & -2.02 & 3.15 & -0.55 \\
\hline Portugal & -0.68 & -0.78 & -0.64 & -1.61 & -1.91 & 4.22 & -3.19 & 0.23 & -2.35 \\
\hline Romania & -1.06 & -0.77 & -1.25 & -1.88 & -1.49 & -0.82 & -3.80 & -1.82 & 1.63 \\
\hline Russia & 0.05 & -0.21 & -3.39 & 0.83 & -1.77 & -1.65 & 0.83 & -1.56 & -2.09 \\
\hline Serbia & 3.53 & -0.05 & -4.83 & -4.68 & -2.23 & -0.59 & -4.57 & -1.62 & -1.28 \\
\hline Slovenia & 4.08 & -1.05 & 1.58 & 0.09 & -0.25 & -0.64 & -3.40 & -0.74 & -0.66 \\
\hline Spain & -1.14 & 0.28 & -1.17 & -1.48 & -0.15 & 0.59 & -2.62 & 0.17 & -1.20 \\
\hline Sweden & -2.79 & -0.79 & 3.15 & 1.82 & 2.86 & -0.93 & -3.45 & -1.55 & -2.59 \\
\hline Switzerland & 2.00 & 0.64 & -1.84 & -1.99 & -0.32 & -1.36 & -2.69 & 2.06 & -0.24 \\
\hline Turkey & -0.19 & -2.42 & -1.48 & -2.66 & -0.63 & 1.83 & -0.85 & 2.43 & -1.32 \\
\hline Ukraine & -0.98 & -1.67 & -3.62 & -1.36 & -3.83 & -3.10 & 3.12 & -3.70 & -3.12 \\
\hline UK & -1.24 & -0.02 & -0.19 & -0.29 & -1.44 & -1.04 & -2.37 & -0.73 & 0.41 \\
\hline
\end{tabular}


Continued voting bias

\begin{tabular}{|c|c|c|c|c|c|c|c|c|c|}
\hline & Hungary & Iceland & Ireland & Israel & Italy & Latvia & Lithuania & Macedonia & Malta \\
\hline Iceland & 2.93 & & & & & & & & \\
\hline Ireland & -1.74 & -0.68 & & & & & & & \\
\hline Israel & 2.89 & -0.77 & -1.12 & & & & & & \\
\hline Italy & -1.80 & -2.48 & -2.78 & $\mathrm{n} / \mathrm{a}$ & & & & & \\
\hline Latvia & -2.35 & 1.10 & 0.81 & -1.64 & $\mathrm{n} / \mathrm{a}$ & & & & \\
\hline Lithuania & -1.23 & -1.14 & 2.48 & -0.34 & -0.37 & 4.38 & & & \\
\hline Macedonia & -2.96 & -1.77 & -2.22 & -1.07 & -0.32 & -1.74 & -2.25 & & \\
\hline Malta & -1.60 & 0.09 & 0.19 & -0.79 & 3.40 & -1.80 & -0.33 & -1.74 & \\
\hline Moldova & -2.49 & -2.81 & -1.31 & -1.36 & -0.87 & -0.26 & -1.97 & -2.48 & -3.04 \\
\hline Norway & 2.28 & 0.18 & 0.44 & -1.00 & -1.13 & 1.07 & -0.90 & -2.07 & -0.57 \\
\hline Netherlands & -2.92 & 3.11 & -0.30 & 1.53 & -4.80 & -1.16 & 0.37 & -1.38 & -0.04 \\
\hline Poland & $\mathrm{n} / \mathrm{a}$ & -1.17 & -1.20 & -0.13 & $\mathrm{n} / \mathrm{a}$ & -0.12 & 0.97 & -1.61 & 0.58 \\
\hline Portugal & $\mathrm{n} / \mathrm{a}$ & 0.17 & 0.31 & -1.41 & $\mathrm{n} / \mathrm{a}$ & -0.04 & -1.15 & $\mathrm{n} / \mathrm{a}$ & -0.91 \\
\hline Romania & 1.58 & -1.53 & -1.27 & 0.36 & 0.42 & -3.52 & -2.74 & -0.98 & -0.85 \\
\hline Russia & -2.83 & -2.54 & -2.12 & 0.95 & -4.51 & -0.52 & 1.24 & -1.59 & -1.15 \\
\hline Serbia & 0.69 & -3.01 & -3.92 & -3.86 & -3.14 & -5.43 & -2.12 & 4.83 & -3.40 \\
\hline Slovenia & -0.79 & -1.48 & -0.22 & -0.68 & -4.38 & 0.53 & 0.79 & 2.03 & -1.48 \\
\hline Spain & -1.30 & -1.08 & -1.33 & -0.13 & 0.81 & -1.86 & -1.25 & -1.84 & -1.71 \\
\hline Sweden & -0.51 & 1.67 & 0.49 & -0.70 & -7.00 & -0.82 & -1.76 & -1.49 & -0.93 \\
\hline Switzerland & -2.41 & 1.13 & -0.70 & -0.55 & -2.25 & -0.97 & 0.80 & -1.11 & -1.27 \\
\hline Turkey & -2.44 & -2.44 & -2.34 & -1.45 & -4.26 & -3.19 & -2.90 & 1.27 & -1.12 \\
\hline Ukraine & -2.88 & -2.94 & -2.23 & -0.19 & -2.49 & -0.40 & -1.19 & -2.03 & -0.19 \\
\hline UK & -2.12 & -0.74 & 4.37 & -1.22 & -0.80 & -0.08 & 0.88 & -1.01 & 1.52 \\
\hline
\end{tabular}


Continued voting bias

\begin{tabular}{|c|c|c|c|c|c|c|}
\hline & Moldova & Norway & Poland & Portugal & Romania & Russia \\
\hline Netherlands & -2.51 & & & & & \\
\hline Poland & -3.70 & -0.20 & & & & \\
\hline Portugal & $\mathrm{n} / \mathrm{a}$ & -0.23 & -1.28 & & & \\
\hline Romania & 2.65 & -1.83 & 0.26 & -0.51 & & \\
\hline Russia & 8.08 & -1.62 & -2.24 & -2.30 & -1.56 & \\
\hline Serbia & 1.86 & -2.34 & -2.62 & -2.80 & -2.43 & -2.39 \\
\hline Slovenia & -3.66 & -2.13 & -0.20 & -1.27 & -0.07 & 0.60 \\
\hline Spain & -3.65 & -0.15 & -1.11 & 4.96 & 2.47 & -2.06 \\
\hline Sweden & -0.56 & -1.74 & 0.33 & -0.79 & -1.57 & -2.85 \\
\hline Switzerland & -2.68 & 2.82 & $\mathrm{n} / \mathrm{a}$ & $\mathrm{n} / \mathrm{a}$ & -2.54 & -1.89 \\
\hline Netherlands & -3.18 & -2.30 & -1.01 & 0.12 & -1.74 & -1.44 \\
\hline Turkey & -2.45 & -1.99 & -1.99 & -2.27 & -0.56 & -3.13 \\
\hline Ukraine & 2.95 & -2.30 & 3.09 & -0.13 & -3.06 & 2.09 \\
\hline UK & -1.66 & -1.24 & -0.10 & -0.64 & -1.15 & -2.07 \\
\hline
\end{tabular}

Continued voting bias

\begin{tabular}{|c|c|c|c|c|c|c|c|c|}
\hline & Serbia & Slovenia & Spain & Sweden & Switzerland & $\begin{array}{l}\text { The } \\
\text { Netherlands }\end{array}$ & Turkey & Ukraine \\
\hline Slovenia & 4.13 & & & & & & & \\
\hline Spain & -4.09 & -0.35 & & & & & & \\
\hline Sweden & -1.82 & -0.48 & -0.38 & & & & & \\
\hline Switzerland & 2.03 & 3.50 & 0.77 & -1.87 & & & & \\
\hline The Netherlands & -0.74 & 1.05 & -0.01 & -0.85 & 1.96 & & & \\
\hline Turkey & -5.88 & -0.81 & -2.51 & -0.93 & 1.82 & 2.05 & & \\
\hline Ukraine & -2.89 & -1.77 & -1.79 & -3.76 & -2.78 & -2.71 & -2.82 & \\
\hline United Kingdom & -4.01 & -1.98 & -0.82 & -0.72 & -1.06 & -0.10 & 0.05 & -1.97 \\
\hline
\end{tabular}

Notes: This table reports the average voting bias for all available pairs of countries in our sample. The voting bias was estimated as the votes given on average per pair minus the average votes given by counterpart countries. Votes available are $0,1,2,3,4,5,6,7,8,10$, and 12 ; therefore, the voting bias may vary between -12 and 12. Note that there are changes to the list of countries that compete from year to year, and therefore the number of years used to estimate the average voting bias per pair varies. ' $\mathrm{n} / \mathrm{a}$ ' indicates that the particular pair of countries never performed in the Eurovision Song Contest in the same year. The sample period was between 1999 and 2013. 
Variable definitions

\begin{tabular}{|c|c|c|}
\hline Variable name & Source & Definition \\
\hline $\begin{array}{l}\text { Ln Number of } \\
\text { Mergers }\end{array}$ & Thomson OneBanker & $\begin{array}{l}\text { The natural logarithm of one plus the number of cross-border } \\
\text { mergers between the two countries }\end{array}$ \\
\hline Voting Bias & $\begin{array}{l}\text { Eurovision Song } \\
\text { Contest website }\end{array}$ & $\begin{array}{l}\text { The average vote between each pair of countries minus the average } \\
\text { vote of the remaining votes available from other countries for the } \\
\text { particular pair over the sample period }\end{array}$ \\
\hline $\begin{array}{l}\text { Cultural Distance - } \\
\text { Hofstede }\end{array}$ & Hofstede website & $\begin{array}{l}\frac{\sum_{\mathrm{k}=1}^{6}\left(\left(\operatorname{Country} y_{\mathrm{i}}-\text { Country }_{\mathrm{j}}\right)^{2} / V_{\mathrm{k}}\right)}{\mathrm{G}} \text { where } k \text { is each dimension (i.e. power } \\
\text { distance, individualism, masculinity, uncertainty avoidance, long- } \\
\text { term orientation, and indulgence) and } V \text { is the variance of the } \\
\text { dimension } k\end{array}$ \\
\hline $\begin{array}{l}\text { Cultural Distance - } \\
\text { Schwartz }\end{array}$ & $\begin{array}{l}\text { https://www.researchg } \\
\text { ate.net/publication/30 } \\
4715744 \text { The_7_Sch } \\
\text { wartz_cultural_value_ } \\
\text { orientation_scores_for } \\
\text { _80_countries }\end{array}$ & $\begin{array}{l}\text { harmony, embeddedness, hierarchy, mastery, affective autonomy, } \\
\text { intellectual autonomy, and egalitarianism) and } V \text { is the variance of } \\
\text { the dimension } k\end{array}$ \\
\hline $\begin{array}{l}\text { Cultural Distance - } \\
\text { WVS }\end{array}$ & $\begin{array}{l}\text { World Values Survey } \\
\text { website }\end{array}$ & $\begin{array}{l}\frac{\left.\sum_{k=1}^{3}\left(\operatorname{Country} y_{i}-\operatorname{Country} y_{j}\right)^{2} / v_{k}\right)}{3} \text { where } k \text { is each dimension (i.e. trust, } \\
\text { authority, and individualism) and } V \text { is the variance of the dimension } \\
k\end{array}$ \\
\hline $\begin{array}{l}\text { Ln Shared Border } \\
\text { Distance }\end{array}$ & CIA World Factbook & $\begin{array}{l}\text { The natural logarithm of the length of the shared border (if any) } \\
\text { between two countries }\end{array}$ \\
\hline Ln Capitals Distance & CIA World Factbook & $\begin{array}{l}\text { The natural logarithm of the distance in kilometers between the } \\
\text { capital cities of two countries }\end{array}$ \\
\hline Song Familiarity & Google trend website & $\begin{array}{l}\text { A continuous variable measuring the number of years in which } \\
\text { citizens of at least one country of a dyad exhibited maximum google } \\
\text { search activity (100) on the counterpart song's name one day before } \\
\text { to three days after each competition }\end{array}$ \\
\hline Shared Language & CIA World Factbook & $\begin{array}{l}\text { The average percentage of citizens speaking each other's language in } \\
\text { a pair }\end{array}$ \\
\hline Shared Religion & $\begin{array}{l}\text { Stulz \& Williamson } \\
(2003)\end{array}$ & $\begin{array}{l}\text { A dummy variable that takes a value of one if two countries share a } \\
\text { primary religion, and zero otherwise }\end{array}$ \\
\hline Shared Legal Origin & CIA World Factbook & $\begin{array}{l}\text { A dummy variable that takes a value of one if two countries share } \\
\text { legal origin, and zero otherwise }\end{array}$ \\
\hline Shared History & $\begin{array}{l}\text { International } \\
\text { Historical Statistics }\end{array}$ & $\begin{array}{l}\text { A dummy variable that takes a value of one if two countries share } \\
\text { history, and zero otherwise }\end{array}$ \\
\hline Shared Region & CIA World Factbook & $\begin{array}{l}\text { A dummy variable that takes a value of one if two countries share } \\
\text { region (ie central Europe, northern Europe, Middle East), and zero } \\
\text { otherwise }\end{array}$ \\
\hline Conflicts & $\begin{array}{l}\text { Correlates of War } \\
\text { (COW) }\end{array}$ & $\begin{array}{l}\text { A continuous variable that measures the number of conflicts with at } \\
\text { least one fatality per country pair }\end{array}$ \\
\hline Tax Difference & WorldBank & $\begin{array}{l}\text { The distance in the average tax rate per pair of countries during the } \\
\text { sample period }\end{array}$ \\
\hline Shared Currency & Wikipedia & $\begin{array}{l}\text { A dummy variable that takes one if two countries shared a currency } \\
\text { during the sample period, and zero otherwise }\end{array}$ \\
\hline Ln GDP & WorldBank & $\begin{array}{l}\text { The natural logarithm of the average GDP between the two countries } \\
\text { during the sample period }\end{array}$ \\
\hline Ln GDP Difference & WorldBank & $\begin{array}{l}\text { The natural logarithm of the absolute distance of the average GDP } \\
\text { between the two countries during the sample period }\end{array}$ \\
\hline
\end{tabular}




\section{Endogeneity mitigation}

To offer some empirical validity on whether endogeneity influences the relation, we followed a standard instrumental variable (IV) approach (e.g., Greene, 2008). We used the following instrumental variables that are expected to be related with voting bias but not necessarily with the number of cross-border mergers. We used a dummy variable (First time) to control for the first year that a country participates in the Eurovision Song Contest because lack of experience may affect a country's performance and the voting pattern. Similarly, Won it before, captures whether a country has won the competition before. In English, captures whether the song was sung in English. A significant percentage of the global population speaks English, and therefore more people may understand the content of the songs. More singers, captures whether the song was performed by one or more singers. Sequence of song, also captures when the song is performed during the event by assigning a value of one if a song appears within the first five or the last five songs, and zero otherwise. There is evidence (e.g., Nuechterlein, Parasuraman \& Jiang, 1983) that concentration levels are relatively high in the early and late stages, and low in between these two stages. Ethnicity, also captures ethnic groups who may vote for the song of their country of origin.

The table below reports the results of instrumental variable estimations. We use yearly data to undertake the analysis. In the first step, we regressed our instrumental variables on the voting bias and estimated the predicted voting bias. In the second step, we regressed the predicted voting bias that arrives from the first stage on the number of cross-border mergers. The results of the first step regression shown in column (1) indicate that the coefficients are to an extent as hypothesized above. In particular, ethnic groups seem to vote for songs from their home countries. Also, songs from a country participating in the Eurovision Song Contest for the first time tend to receive relatively low scores. The F-statistic of the regression is larger than ten indicating that the variables are relatively good instruments. More importantly, the results of the second-step regression shown in column (2) indicate that the relation is unlikely to be the outcome of reverse causality. Voting bias is related positively with the number of cross-border mergers.

\begin{tabular}{|c|c|c|}
\hline & $\begin{array}{l}\text { Voting Bias (Annual) } \\
\text { First Step Regression } \\
\text { (1) }\end{array}$ & $\begin{array}{c}\text { Ln Number of Mergers (Annual) } \\
\text { 2SLS } \\
(2)\end{array}$ \\
\hline Voting Bias (Annual) & & $\begin{array}{c}0.155 \\
(0.000)\end{array}$ \\
\hline First Time & $\begin{array}{l}-2.771 \\
(0.000)\end{array}$ & \\
\hline Won It Before & $\begin{array}{c}0.121 \\
(0.162)\end{array}$ & \\
\hline Hosting & $\begin{array}{l}-0.193 \\
(0.166)\end{array}$ & \\
\hline In English & $\begin{array}{c}0.105 \\
(0.208)\end{array}$ & \\
\hline More Singers & $\begin{array}{c}-0.156 \\
(0.775)\end{array}$ & \\
\hline Sequence of Song & $\begin{array}{c}0.021 \\
(0.846)\end{array}$ & \\
\hline Ln Ethnicity & $\begin{array}{l}1.248 \\
(0.000)\end{array}$ & \\
\hline Constant & $\begin{array}{c}0.009 \\
(0.953)\end{array}$ & $\begin{array}{c}0.711 \\
(0.000)\end{array}$ \\
\hline Year Dummies & Yes & Yes \\
\hline Other controls & No & No \\
\hline $\mathrm{N}$ & 4337 & 4337 \\
\hline R-squared Adjusted & 0.120 & -0.030 \\
\hline F-Statistic & $\begin{array}{c}61.97 \\
(0.000)\end{array}$ & \\
\hline
\end{tabular}

Notes: P-values are reported in parenthesis. 


\section{REFERENCES}

Greene, W. 2008. Econometric analysis. $6^{\text {th }}$ Edition. Upper Saddle River: Pearson PrenticeHall.

Nuechterlein, K., Parasuraman, R., \& Jiang, Q. 1983. Visual sustained attention: Image degradation produces rapid sensitivity decrement over time. Science, 220: 327-329. 